\title{
UTJECAJ STAROSTI I SKLADIŠTENJA CEMENTA NA NJEGOVU KVALITETU
}

\section{Sandra Juradin}

Sveučilište u Splitu, Fakultet građevinarstva, arhitekture i geodezije, docent Antonia Gambiraža

Sveučilište u Splitu, Fakultet građevinarstva, arhitekture i geodezije, student

Sažetak: Cement koji je nepropisno uskladišten nakon godine dana gubi i do $50 \%$ svoje čvrstoće. U radu su ispitana svojstva uskladištenih uzoraka cementa starih 30 godina. Radi usporedbe, ispitana su i dva nova cementa: jedan loše uskladišten, a drugi uzet iz tek otvorene vreće. Rezultati ispitivanja uspoređeni su s vrijedećim standardima i referentnim rezultatima iz vremena proizvodnje cemenata.

Ključne riječi: ispitivanja cementa, skladištenje cementa, starost cementa, vrijeme vezanja, čvrstoća cementa

\section{EFFECT OF AGE AND STORAGE OF CEMENT ON ITS QUALITY}

\begin{abstract}
Cement that is improperly stored after one year losing up to $50 \%$ of its strength. The paper investigates the properties of stored samples of cement of 30 years. For comparison are examined and two new cements: one incorrectly stored and the other taken from newly opened bag. Test results are compared with applicable standards and reference results from the time of production of cement.
\end{abstract}

Keywords: cement testing, storage of cement, age of cement, setting time, cement strength 


\section{Uvod - skladištenje cementa}

Ako je cement dugo stajao na vlažnom zraku ili bio loše uskladišten, vlaga iz zraka uzrokuje proces hidratacije pa uporabna vrijednost cementa znatno opada [1]. Cement koji je nepropisno uskladišten na duži period vremena, gubi na svojoj čvrstoći:

- nakon 3 mjeseca 20 do $30 \%$

- nakon 6 mjeseci 30 do $40 \%$

- nakon godinu dana 40 do $50 \%$ početne čvrstoće cementa [2].

Da bi cement bio duže vremena uskladišten bez utjecaja na njegovu kvalitetu, mora biti u ambalaži nepropusnoj za zrak, bilo da se radi o čeličnom silosu ili polietilenskim vrećama. Od ukupne potrošnje cementa u Hrvatskoj, potrošnja cementa pakiranog u papirnate vreće iznosi preko $40 \%$ [3]. Da bi se izbjegli negativni utjecaji na kvalitetu cementa, kod skladištenja je potrebno maksimalno poštivanje određenih uvjeta. U većini slučajeva skladišta na gradilištu su izgrađena za količinske potrebe cementa od nekoliko dana. lako su takva skladišta privremena, moraju se prilagoditi sljedećim zahtjevima [2]:

- zidovi moraju biti otporni na vlagu i paru

- krov mora biti vodonepropustan

- pod mora biti odignut od tla radi sprječavanja dotoka vode

- za dugotrajnije čuvanje, cement treba složiti na suhe drvene palete

- ako se na skladištu predviđaju prozori, najbolje je da ih je što manje i da budu čvrsto zatvoreni kako bi se spriječio ulaz atmosferske vlage

- za izgradnju skladišta koristiti suhomontažne poluproizvode ili konstrukcije.

Slaganje vreća bi trebalo biti takvo da je prikladno za iznošenje skladištenog i unošenje novog cementa $s$ potrebnim dovoljnim manipulativnim prostorom. Nijedna vreća cementa ne bi smjela biti u kontaktu s vanjskim zidom (slika 1). Kod slaganja vreća prema vanjskim zidovima treba voditi računa o prostoru prozračivanja, cirkulaciji zraka zbog sprječavanja kondenzacije vlage na vrećama cementa koje su najčešće papirnate. Same vreće cementa treba slagati i križati jedne preko drugih kako bi se izbjegli zračni jastuci i potencijalna opasnost od kondenzacije vlage na posloženim vrećama. Potrebno je voditi računa i o visini slaganja kako se ne bi, zbog opterećenja, javljalo stvaranje gruda u cementu. Pažljivo rukovanje prilikom prijenosa i slaganja je nužno kako ne bi došlo do oštećenja vreća. Za veću sigurnost tijekom kišnih perioda, hrpe vreća cementa bi trebale biti prekrivene kompletno vodootpornim folijama.
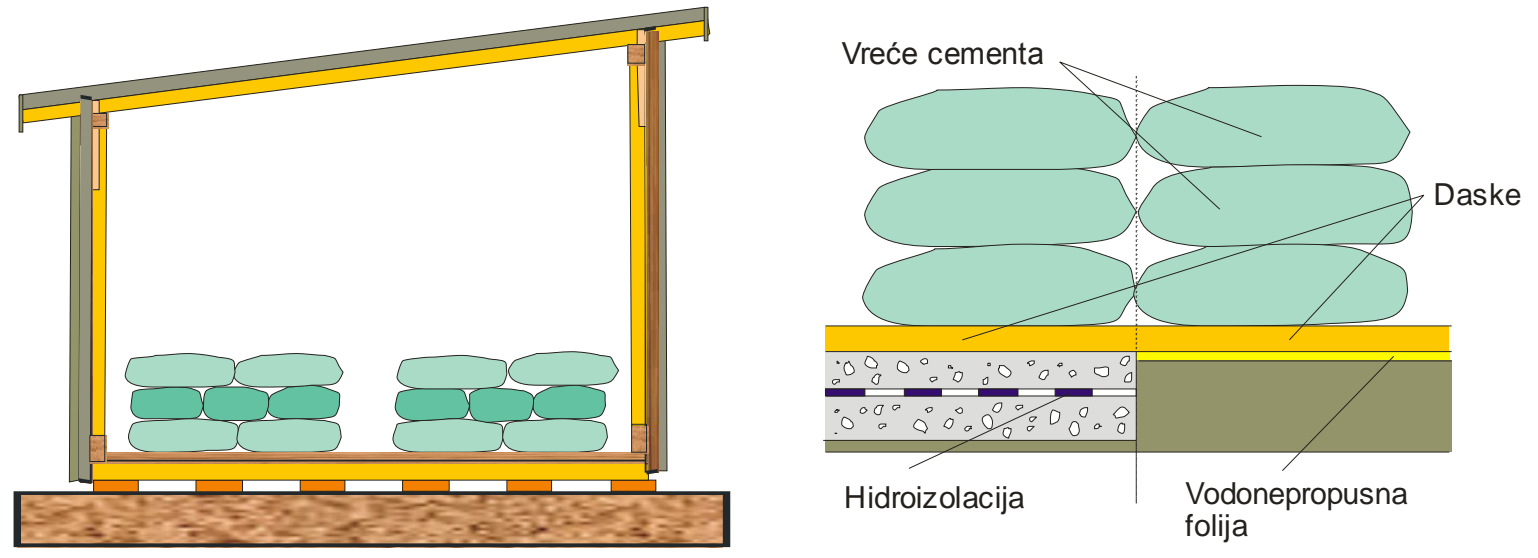

\section{Slika 1 - Skladište cementa i podloga za uskladištenje cementa u vrećama $[1,4]$}

Kod skladištenja različitih tipova cementa treba voditi računa o razvrstavanju po tipu cementa i datumu proizvodnje, što je uočljivo istaknuto na samim vrećama. Prilikom slaganja vreća također treba paziti na mogućnost korištenja cementa starijeg datuma proizvodnje.

Prema [4]: „U slučaju dužeg ležanja, naročito u jesensko i zimsko doba, cement se mora premještati svakih 10 - 15 dana. Premještanje se vrši na taj način da se svaka vreća premjesti na neko drugo mjesto, pri čemu se dobro „izgnjavi“; treba voditi računa da se vreća ne postavi u isti položaj u kakvom je ranije ležala“. 
Manja količina cementa koja ostane u otvorenoj vreći (ili čak puna vreća cementa) može biti sačuvana na duži period ako se cement stavi u neoštećenu polietilensku vreću. Što su vreće deblje i čvršće, napravljene od vodonepropusnih materijala, to su prikladnije za dugotrajnije čuvanje cementa.

\section{Dosadašnja ispitivanja utjecaja skladištenja na kvalitetu cementa}

Utjecaj skladištenja na kvalitetu portland cement je značajan proizvođačima, prodavačima i potrošačima. Svrha dosadašnjih ispitivanja bila je utvrditi utjecaj različith uvjeta i perioda skladištenja na kvalitetu betona i morta, te proučiti utjecaj određenih metoda za zaštitu cementa tijekom skladištenja.

Abrams [5] je ispitivao cemente koje je dvije godine skladištio u laboratoriju, u podrumu Lewis instituta i u spremištu na dvorištu. Nakon dvije godine svi su cementi premješteni u laboratorij. Cement je stajao u jutenim vrećama. $U$ drugoj ispitnoj grupi cement je čuvan u spremištu, ali u vodootpornim papirnatim vrećama i u dvostrukom pakiranju: jutena i papirnata vreća, dok je u trećoj grupi cement u spremištu pakiran u platnene vreće prekrivene tankim slojevima hidratiziranog vapna ili portland cementa.

Rezultati ispitivanja pokazali su da je smanjenje čvrstoće bilo najveće za cement skladišten u spremištu, a najmanje za onaj skladišten u laboratoriju. Uočeno je da utjecaj skladištenja uvelike ovisi o ispitnoj starosti uzoraka morta, slika 2. Kvaliteta cementa pakiranog u papirnate vreće (oba tipa) ne razlikuje se od kvalitete cementa u platnenim vrećama. Uporaba portland cementa i hidratiziranog vapna kao pokrivača za platnene vreće ne daje rezultate koji bi bili isplativi. Značajnija pojava grudica u cementu uočena je kod uzoraka koji su stajali uskladišteni više od 2 godine.

McCoy i Helms [6] ispitivali su utjecaj skladištenja na kvalitetu aeriranog cementa. Utjecaj vremena i uvjeta skladištenja na sadržaj zraka, gubitak žarenjem, specifičnu površinu i slobodno vapno utvrđeni su u intervalima tijekom perioda od 5 godina. Ova ispitivanja pokazuju da cement starenjem ne doživljava značajne promjene u navedenim svojstvima (ni u vremenu vezanja, ni tlačnoj čvrstoći), ako je propisno skladišten da se spriječi ikakvu reakcija s vlagom ili ugljičnim dioksidom.
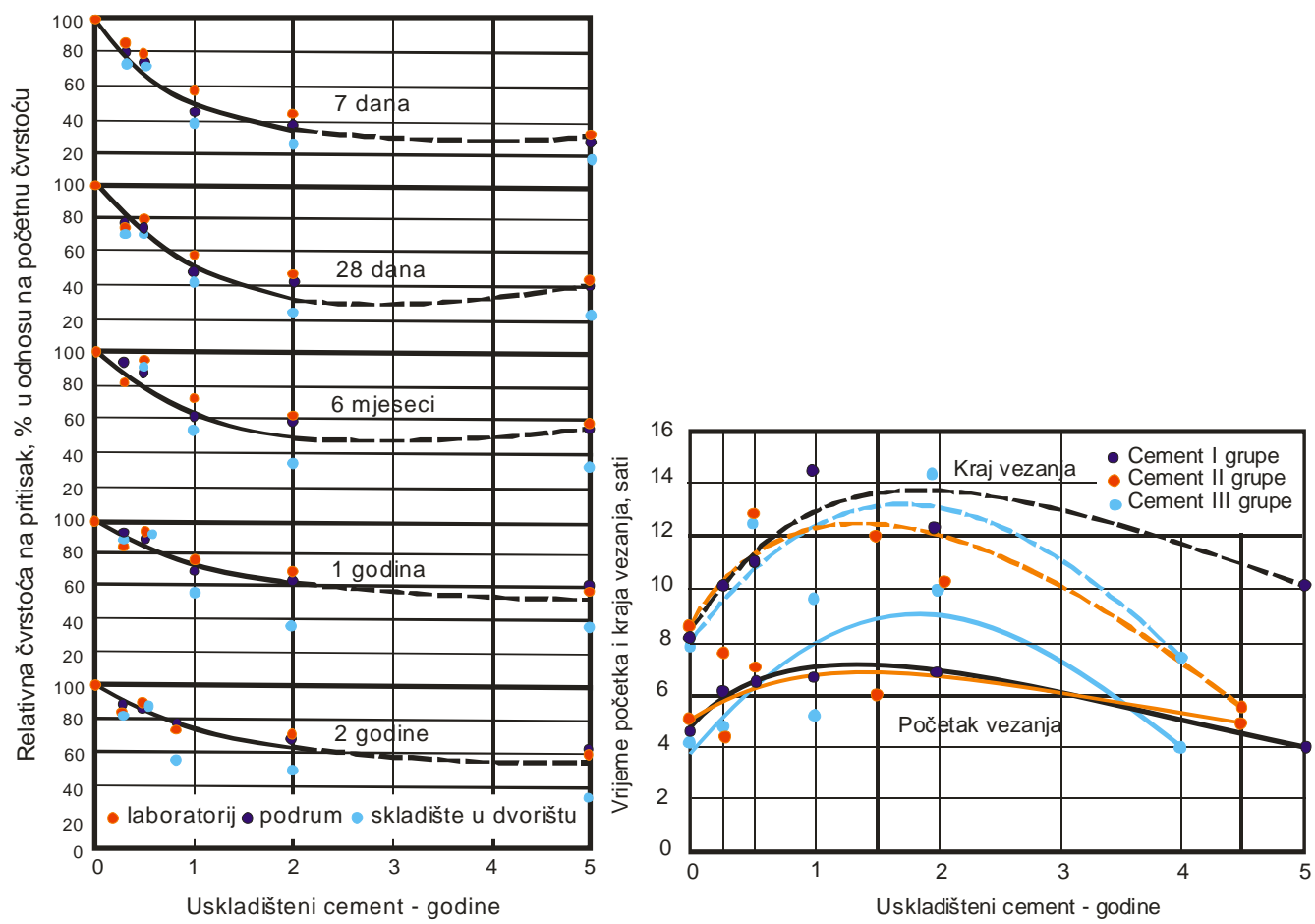

Slika 2 - Utjecaj skladištenja na relativnu čvrstoću (cement I grupe) i vrijeme vezanja cementa - prosječne krivulje za sve uvjete skladištenja [5] 
Gonnerman i Timms [7] su također ispitivali utjecaj različitih uvjeta skladištenja na kvalitetu portland cementa. Rezultati ispitivanja prikazani su na slici 3. Zaključci ovog ispitivanja su:

- najbolje rezultate postižu cementi skladišteni u betonskom silosu tvornice i u hermetički zatvorenim kantama

- ostali rezultati su dobri do 4 mjeseca skladištenja.

lako se već više od jednog stoljeća provode ispitivanja o utjecaju starosti, odnosno dugotrajnijeg skladištenja cementa, ona su ipak malobrojna i uglavnom starijeg datuma pa se nameće potreba detaljnijeg ispitivanja svojstava dugotrajnije skladištenog cementa, što je i tema ovog rada.

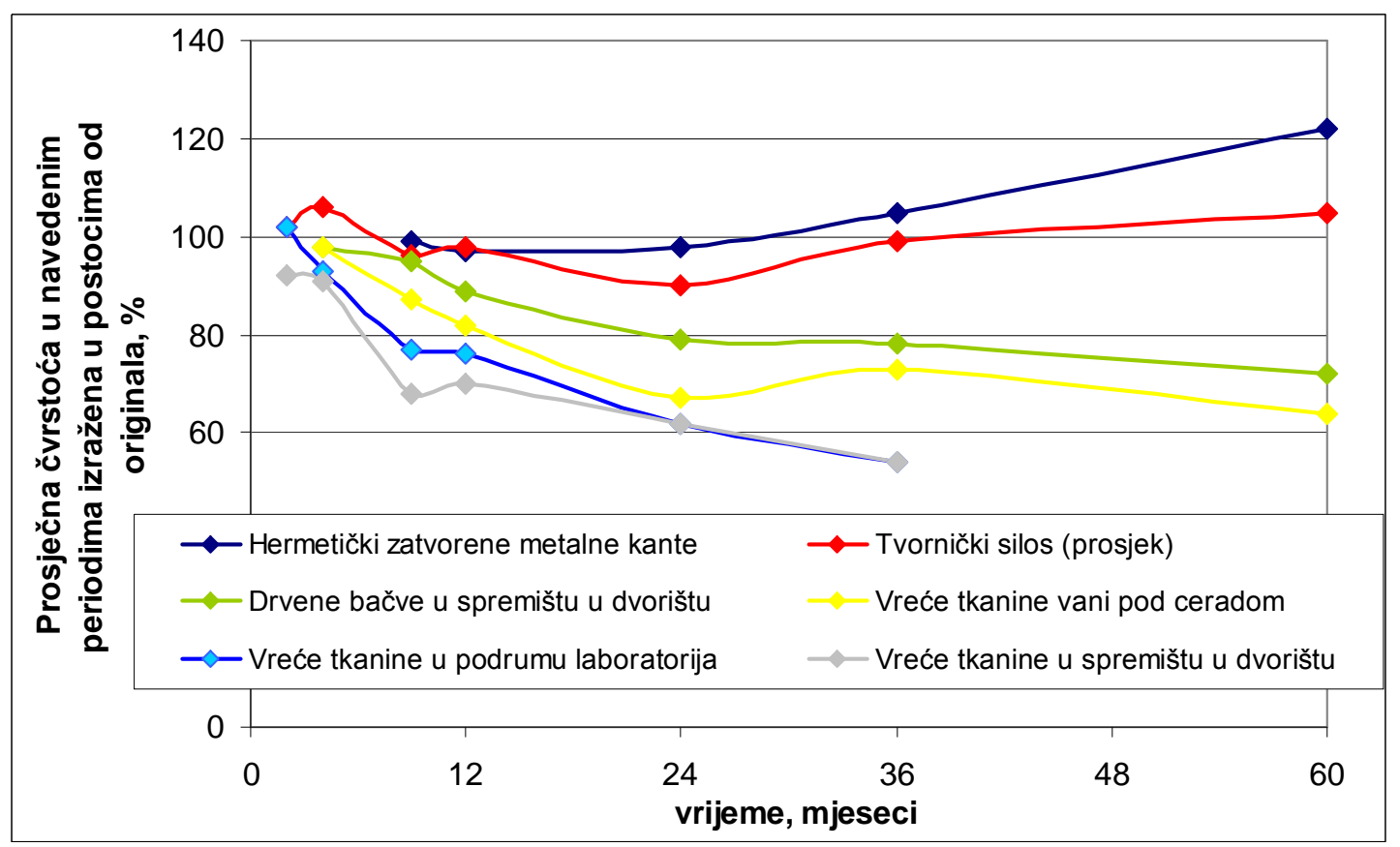

\section{Slika 3 - Utjecaj skladištenja na tlačnu čvrstoću betona [7]}

\section{Eksperimentalni dio}

\subsection{Materijali i metode}

Prilikom dokazivanja postignute kvalitete cemenata, ostatci svih uzoraka cementa se moraju čuvati u ambalaži nepropusnoj za zrak najmanje 6 mjeseci. Nekoliko takvih uzoraka cemenata, nakon dokazivanja postignute kvalitete, ostalo je 30 godina u laboratoriju fakulteta. Formirana su četiri uzorka za eksperimentalni dio rada kojemu je cilj utvrditi kako vrijeme i način skladištenja utječe na karakteristike cementa (vrijeme vezanja, finoću mliva, postojanost volumena i čvrstoću). Da bi ovaj utjecaj sagledali što bolje, ispitivanje je prošireno na još dva "nova“ uzorka cementa: jedan uzorak je cement CEM II/B-M (S-LL) 42,5N koji je stajao otvoren u papirnatoj vreći oko četiri mjeseca i još 10 dana ostavljen u vlažnoj komori za njegu uzoraka, te drugi uzorak istog tipa cementa, ali uzet iz potpuno nove/neotvorene vreće cementa.

Oznake uzoraka, vrste cemenata i datumi uzorkovanja prikazani su u tablici 1.

Kako su cementi proizvedeni i uskladišteni u vrijeme dok su vrijedili prijašnji propisi, prema istima su i označeni. Uzorak oznake 1 je cement s dodatkom do $5 \%$ pucolana i do $15 \%$ zgure, marke 350 , što bi odgovaralo tlačnoj čvrstoći od $35 \mathrm{MPa}$. Uzorci cementa broj 2 i 3 su s dodatkom $15-30 \%$ zgure, klase 45 , odnosno tlačne čvrstoće $45 \mathrm{MPa}$, te sporog prirasta črrstoće. Uzorak cementa broj 4 je s dodatkom do $20 \%$ zgure i tlačne čvrstoće $45 \mathrm{MPa}$. 
Tablica 1 - Vrste cementa i datumi uzorkovanja

\begin{tabular}{|c|l|c|c|}
\hline Uzorak & \multicolumn{1}{|c|}{ Vrsta cementa } & Tvornica cementa & Datum uzorkovanja \\
\hline 1 & PC 5p 15z-350 & Prvoborac & 03.06 .1980$. \\
\hline 2 & PC 30z 45S & Partizan & 1983. \\
\hline 3 & PC 30z 45S & Partizan & 21.03 .1983$. \\
\hline 4 & PC 20z 45 & 10. kolov0z & 02.07 .1983$. \\
\hline 5 & CEM II/B-M (S-LL) 42,5N (stari) & Dalmacijacement & $\begin{array}{c}\text { iz vreće otvorene u 11. mjesecu } \\
\text { 2011., uzorak je uzet 19.03.2012. }\end{array}$ \\
\hline 6 & CEM II/B-M (S-LL) 42,5N (novi) & Dalmacijacement & 19.03 .2012$. \\
\hline
\end{tabular}

Uzorci cemenata broj 5 i 6 su označeni prema vrijedećim normama pa in ne treba posebno opisivati. $\mathrm{Na}$ uzorcima se planiraju napraviti sljedeća ispitivanja: finoća mliva prosijavanjem na situ $0.09 \mathrm{~mm}$, postojanost volumena, količina vode potrebna za postizavanje paste standardne konzistencije, vrijeme početka i kraja vezanja, te čvrstoća na savijanje i pritisak nakon 2 i 28 dana starosti. Cementi 2, 3 i 4 trebali su biti ispitani nakon 3 dana starosti, ali su zbog tehničkih uvjeta ispitani nakon 2 dana. Cement oznake 1 ispitan je nakon samo 28 dana jer nije bilo dostatno materijala.

Da bi se sadašnii rezultati mogli usporediti s rezultatima od prije 30 godina, pretražena je arhiva rezultata ispitivanja na IGH PC Split, koji je kao ovlaštena neutralna institucija provodio kontrolu kvalitete cementa. Uzete su srednje vrijednosti svih statističkih rezultata iz godine proizvodnje cementa i dvije susjedne godine. Prema arhivi, broj uzetih i ispitanih uzoraka odgovara količini od 602200 proizvedenih tona cementa. Referentne vrijednosti su dane u tablici 2.

Tablica 2 - Prosječne vrijednosti srednje, karakteristične, minimalne i maksimalne čvrstoće na savijanje $\left(\mathrm{f}_{\mathrm{s}}\right) \mathrm{i}$ pritisak $\left(f_{p}\right)$, podatci iz perioda 1980.-1984. godine [8]

\begin{tabular}{|l|l|c|c|c|c|c|c|c|c|}
\hline \multirow{2}{*}{ Tvornica } & \multirow{2}{*}{ Oznaka cementa } & \multicolumn{2}{|c|}{$X_{\text {srednje }}$} & \multicolumn{2}{|c|}{$X_{\text {karakter. }}$} & \multicolumn{2}{c|}{$X_{\min }$} & \multicolumn{2}{c|}{$X_{\max }$} \\
\cline { 3 - 10 } & & $f_{s}$ & $f_{p}$ & $f_{s}$ & $f_{p}$ & $f_{s}$ & $f_{p}$ & $f_{s}$ & $f_{p}$ \\
\hline Prvoborac & PC 5p15z 35(0) & 7,08 & 39,77 & 6,62 & 36,68 & 6,40 & 38,91 & 7,47 & 44,04 \\
\hline Partizan & PC 30z 45s & 7,53 & 46,69 & 6,99 & 43,82 & 7,07 & 42,86 & 8,24 & 50,00 \\
\hline 10.kolovoz & PC 20z 45 & 7,18 & 44,98 & 6,77 & 42,26 & 6,66 & 43,03 & 7,83 & 49,91 \\
\hline
\end{tabular}

Pretraživanjem diplomskih radova iz tog vremena, pronađeni su izvještaji IGH o ispitivanju cemenata, a odnose na fizikalno-mehanička svojstva ispitnih cemenata PC $20 z 45$ i PC $30 z$ 45S. Referentni podatci o finoći mliva, vremenu vezanja, postojanosti volumena i ranoj čvrstoći dani su u tablici 3. Podatci su dobiveni na osnovi ispitivanja jednog uzorka cementa koji je poslan na testiranje u laboratorij IGH, za potrebe spomenuth diplomskih radova

Tablica 3 - Fizikalno - mehanička svojstva cementa PC $20 z 45$ i PC $30 z$ 45S, [9, 10]

\begin{tabular}{|c|c|c|c|}
\hline Fizikalno mehanička svojstva & Uvjeti JUS-a & PC $20 z 45$ & PC 30z 45S \\
\hline $\begin{array}{l}\text { Finoća mliva (ostatak na situ veličine otvora oka 0,09 } \\
\text { mm), najviše \% }\end{array}$ & $\operatorname{Max} 10 \%$ & $3,3 \%$ & $1,6 \%$ \\
\hline Specifična površina po Bleinu, najmanje $\mathrm{cm}^{2} / \mathrm{g}$ & Min 2400 & $2898 \mathrm{~cm}^{2} / \mathrm{g}$ & $3311 \mathrm{~cm}^{2} / \mathrm{g}$ \\
\hline $\begin{array}{l}\text { Zapreminska masa bez pora i šupljina, najmanje } \\
\mathrm{g} / \mathrm{cm}^{3}\end{array}$ & & $3,09 \mathrm{~g} / \mathrm{cm}^{3}$ & $3,08 \mathrm{~g} / \mathrm{cm}^{3}$ \\
\hline 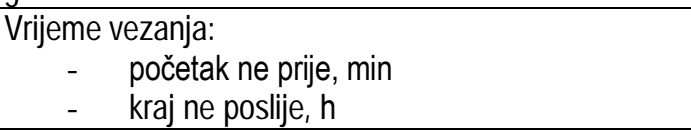 & $\begin{array}{l}\min 1 \text { sat } \\
\max 10 \text { sati }\end{array}$ & $\begin{array}{l}2 \text { sata i } 45 \text { minuta } \\
3 \text { sata i } 30 \text { minuta }\end{array}$ & $\begin{array}{l}2 \text { sata i } 45 \text { minuta } \\
3 \text { sata i } 15 \text { minuta }\end{array}$ \\
\hline $\begin{array}{l}\text { Voda potrebna za standardnu konzistenciju, najviše, } \\
\%\end{array}$ & & $27,50 \%$ & $25 \%$ \\
\hline Postojanost volumena na kolačima & & postojan & postojan \\
\hline $\begin{array}{l}\text { Postojanost volumena prema Le Chatelieru - } \\
\text { povećanje razmaka kazaljki, najviše, } \mathrm{mm}\end{array}$ & $\max 10 \mathrm{~mm}$ & $2,5 \mathrm{~mm}$ & $0,0 \mathrm{~mm}$ \\
\hline Čvrstoća na savijanje 3 dana & 3,5 & $3,65 \mathrm{MPa}$ & $4,59 \mathrm{MPa}$ \\
\hline Čvrstoća na pritisak 3 dana & 14,0 & $20,7 \mathrm{MPa}$ & $24,5 \mathrm{MPa}$ \\
\hline
\end{tabular}


Za cement CEM II/B-M (S-LL) 42,5N postoje deklarirani podatci proizvođača, a prikazani su tablicom 4. Uzorci $5 \mathrm{i}$ 6 će se i međusobno uspoređivati.

Tablica 4 - Deklarirana svojstva uzoraka cementa CEM II/B-M (S-LL) 42,5N; preuzeta iz Tehničke upute [11]

\begin{tabular}{|c|c|c|}
\hline CEM II/B-M (S-LL) 42,5N & Tipična analiza & Zahtjev norme \\
\hline Postojanost volumena (Le Chatelier) & $1 \mathrm{~mm}$ & $\leq 10 \mathrm{~mm}$ \\
\hline Početak vremena vezanja & $140 \pm 30 \mathrm{~min}$ & $\geq 60 \mathrm{~min}$ \\
\hline \multicolumn{3}{|l|}{ Mehanička svojstva } \\
\hline Rana čvrstoća (2 dana) & $21 \pm 2 \mathrm{MPa}$ & $\geq 10$ \\
\hline Normirana čvrstoća (28 dana) & $47 \pm 2 \mathrm{MPa}$ & $\geq 42,5 ; \leq 62,5$ \\
\hline
\end{tabular}

Osim referentnih podataka, dobivene rezultate je potrebno usporediti i s uvjetima standarda. Za sve uzorke u tablici dani su uvjeti standarda koji su vrijedili u to vrijeme. Uvjeti standarda za sve ispitne uzorke dani u tablici 5.

Tablica 5 - Standardom propisane minimalne čvrstoće [12-14]

\begin{tabular}{|c|c|c|c|c|}
\hline Klasa cementa & \multicolumn{4}{|c|}{ Minimalne čvrstoće, MPa } \\
\hline \multirow{3}{*}{350} & \multicolumn{2}{|l|}{7 dana } & \multicolumn{2}{|l|}{28 dana } \\
\hline & savijanje & pritisak & savijanje & pritisak \\
\hline & 4,0 & 20,0 & 5,0 & 31,5 \\
\hline \multirow{2}{*}{$45 \mathrm{~S}$} & \multicolumn{2}{|l|}{3 dana } & \multicolumn{2}{|l|}{28 dana } \\
\hline & 3,5 & 14,0 & 5,5 & 40 \\
\hline \multirow{3}{*}{$42,5 \mathrm{~N}$} & \multicolumn{2}{|l|}{2 dana } & \multicolumn{2}{|l|}{28 dana } \\
\hline & \multicolumn{2}{|c|}{ Rana čvrstoća - pritisak } & \multicolumn{2}{|c|}{ Normirana čvrstoća - pritisak } \\
\hline & \multicolumn{2}{|c|}{$\geq 10,0(\geq 8,0)$} & $\geq 42,5(\geq 40,0)$ & $\leq 62,5$ \\
\hline
\end{tabular}

\subsection{Rezultati i rasprava}

Finoća mliva. Radi odstranjivanja grudica koje su pri proizvodnji slučajno dospjele u cement ili su se formirale tijekom perioda skladištenja, cement se najprije prosije na situ otvora $1 \mathrm{~mm}$. Rezultati sijanja su pokazali da se u nekim uzorcima cementa formirala značajna količina grudica koju je potrebno odstraniti kako bi postigli kvalitetnije rezultate svih ispitivanja. Najveću količinu grudica sadržavali su uzorci cemenata 1 i 5 , tablica 6 . Zatim se finoća mliva odredila metodom prosijavanja na situ $0,09 \mathrm{~mm}$ te se utvrdio ostatak na situ i iskazao u \% u odnosu na početnu masu uzorka. Rezultati su prikazani u tablici 6.

\section{Tablica 6 - Finoća mliva cementa}

\begin{tabular}{|c|c|c|}
\hline Uzorak & Ostatak na situ 1 mm (\%) & Ostatak na situ 0.09 mm (\%) \\
\hline 1 & 14,9 & 10,2 \\
\hline 2 & 4,5 & 2,8 \\
\hline 3 & 3,8 & 2,0 \\
\hline 4 & 10,1 & 2,0 \\
\hline 5 & 15,2 & 1,4 \\
\hline 6 & - & 1,6 \\
\hline
\end{tabular}

S obzirom da vrijednost finoće mliva smije iznositi maksimalno 10\%, iz tablice se vidi da jedino uzorak cementa broj 1 prekoračuje dozvoljenu vrijednost. Međutim, prema tadašnjem propisu JUS B. C.8. 023 (1.VIII 1976.) [13], dozvoljena količina ostatka na situ od $0,09 \mathrm{~mm}$ bila je $15 \%$, pa je moguće da je i tada cement imao veću količinu ostatka jer je količina od 10,2\% u okviru tadašnjih propisa. Ako usporedimo rezultate iz tablice $6 \mathrm{~s}$ referentnim vrijednostima u tablici 3 , uzorci 2 i 3 imaju nešto veću, a uzorak 4 čak manju vrijednost od referentne. 
Standardna konzistencija. Kako bi se ispitalo vrijeme vezanja i postojanost volumena, potrebno je napraviti cementnu pastu standardne konzistencije. Za svaki uzorak cementa određena je količina vode potrebna da bi se postigla standardna konzistencija (tablica 7). Sve vrijednosti kreću se u dozvoljenim granicama od $23-32 \%$ mase cementa.

\section{Tablica 7 - Količina vode potrebna za pripremu paste standardne konzistencije}

\begin{tabular}{|l|c|c|c|c|c|c|}
\hline Uzorak & 1 & 2 & 3 & 4 & 5 & 6 \\
\hline Količina vode (\%) & 28 & 25,8 & 25,8 & 26,2 & 27,8 & 26,8 \\
\hline
\end{tabular}

Postojanost volumena ispitala se prema HRN EN 196-3:2005, odnosno JUS B.C8.023. Za ocjenu postojanosti volumena mjerodavna je razlika između igala prije i nakon kuhanja uzorka u Le Chatelierovim kalupima, a koja ne smije biti veća od $10 \mathrm{~mm}$. Izmjerene vrijednosti dane su u tablici 8.
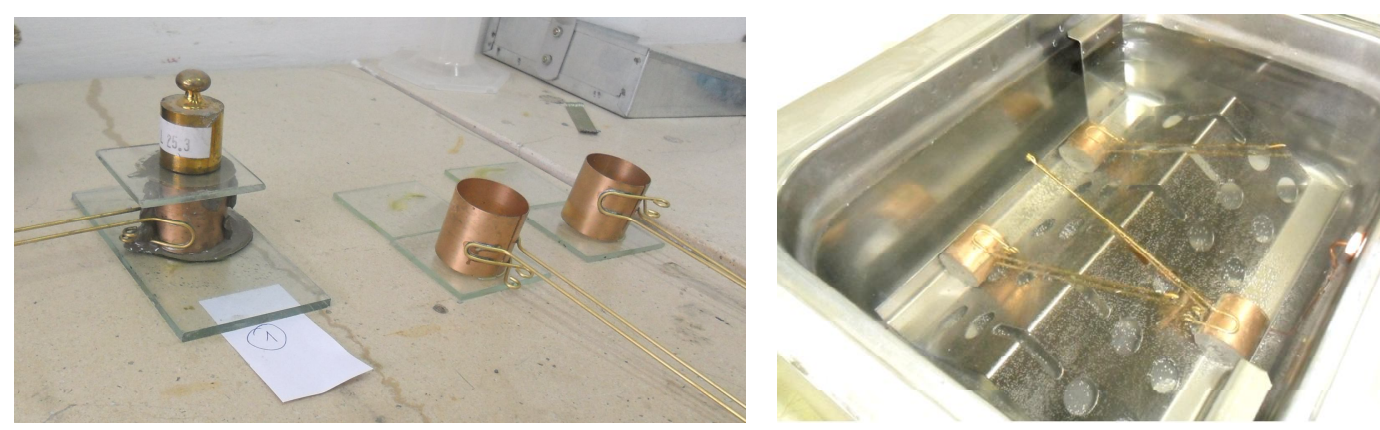

Slika 4 - Le Chatelierovi prsteni - ispitivanje postojanosti volumena

Razlika $d_{2}-d_{1}(m m)$ pokazuje da su svi uzorci cementa volumno postojani.

Tablica 8 - Postojanost volumena cementa

\begin{tabular}{|c|c|c|c|}
\hline Uzorak & $\mathrm{d}_{1}(\mathrm{~mm})$ & $\mathrm{d}_{2}(\mathrm{~mm})$ & $\mathrm{d}_{2}-\mathrm{d}_{1}(\mathrm{~mm})$ \\
\hline 1 & 8 & 9 & 1 \\
\hline 2 & 6,5 & 7,5 & 1 \\
\hline 3 & 9 & 10 & 1 \\
\hline 4 & 10 & 10 & 0 \\
\hline 5 & 9 & 9 & 0 \\
\hline 6 & 8 & 8 & 0 \\
\hline
\end{tabular}

Vrijeme vezanja Vrijeme početka i kraja vezanja ispitalo se na pasti standardne konzistencije, u Vicatovom aparatu. Dobiveni rezultati ispitivanja dani su na slici 5.

Važeće norme za portland cement definiraju da vrijeme početka vezanja ne smije biti kraće od jednog sata, što ispunjavaju svi uzorci. U starim normama bilo je propisano i vrijeme kraja vezanja cementa koje nije smjelo biti duže od deset sati, što opet svi cementi zadovoljavaju. Međutim, uzorci 1 i 5 trebaju najviše vremena da bi počelo vezanje, preko 5 sati, a kraj vezanja im je malo prije 9 sati od kontakta cementa i vode. Uzorci 2, 3 i 4 počinju vezati sa zakašnjenjem od oko 45 minuta u odnosu na referentnu vrijednost iz tablice 3 . Kod uzoraka 2 i 3, razlika vremena između početka i kraja vezanja sada i u odnosu na referentne vrijednosti je oko 20 minuta, dok je kod uzorka 4 ostala ista. 


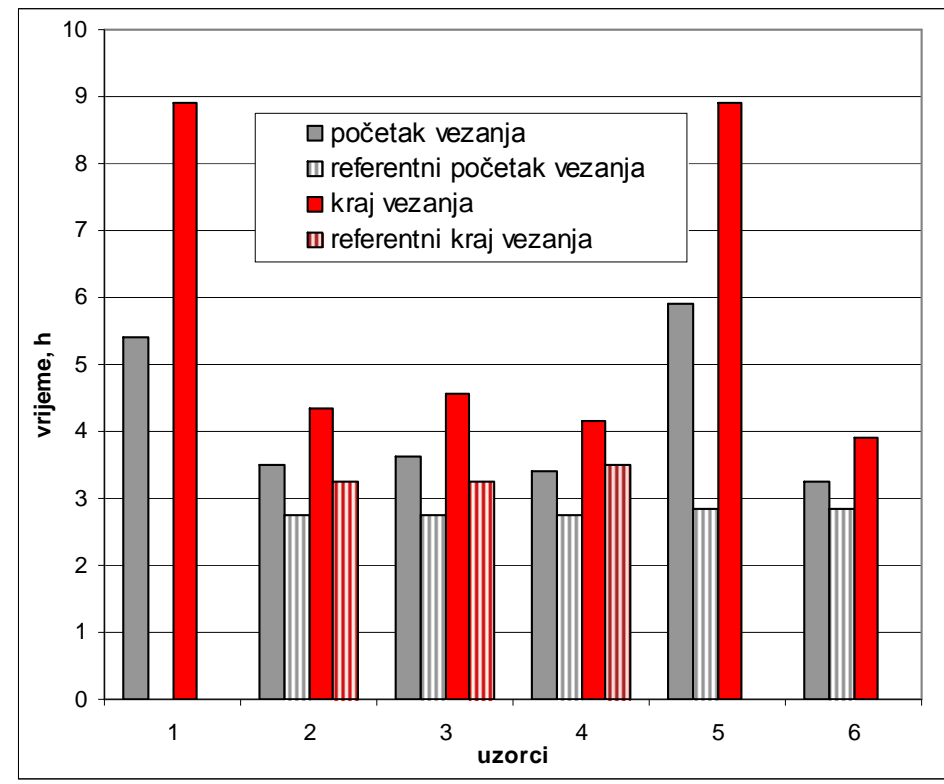

Slika 5 - Početak i kraj vezanja cementa

Čvrstoće. Za ispitivanje čvrstoće na savijanje i pritisak napravljene su standardne_mortne prizmice s normnim pijeskom SNL, porijeklom iz Francuske. Kako se prije 30 godina koristio drugi standardni pijesak, moguć je i utjecaj pijeska na čvrstoću prizmica u granicama do $10 \%$. Svježi mort ugrađen je u kalupe na vibrostolu, te 24 sata čuvan u vlažnoj komori relativne vlažnosti zraka od najmanje $90 \%$, nakon čega su uzorci izvađeni iz kalupa i potopljeni u vodu do trenutka ispitivanja. Rezultati ispitivanja za uzorke 1, 2, 3 i 4 dani su na slikama 6 -9, a uzorci 5 i 6 su samo komentirani u tekstu.

Čvrstoća na savijanje i pritisak, nakon 2 dana. Vlačne i tlačne čvrstoće su na uzorcima 2, 3 i 4 ispitane nakon 2 dana, a stare norme su vrijednosti rane čvrstoće definirale nakon 3 dana, pa je prilično teško usporediti rezultate. Međutim, prema slici 6 , uzorak 4 je već ispitivanjem nakon 2 dana postigao veću vrijednost od referentne vrijednosti iz tablice 3 i traženog uvjeta standarda nakon starosti od 3 dana. Uzorci 2 i 3 bi vjerojatno dosegli vrijednosti propisane standardom, ali ne i referentnu čvrstoću. Uzorak 5 je dosegao samo $20 \%$ vrijednosti vlačne čvrstoće uzorka 6 koja iznosi 4,96 MPa.

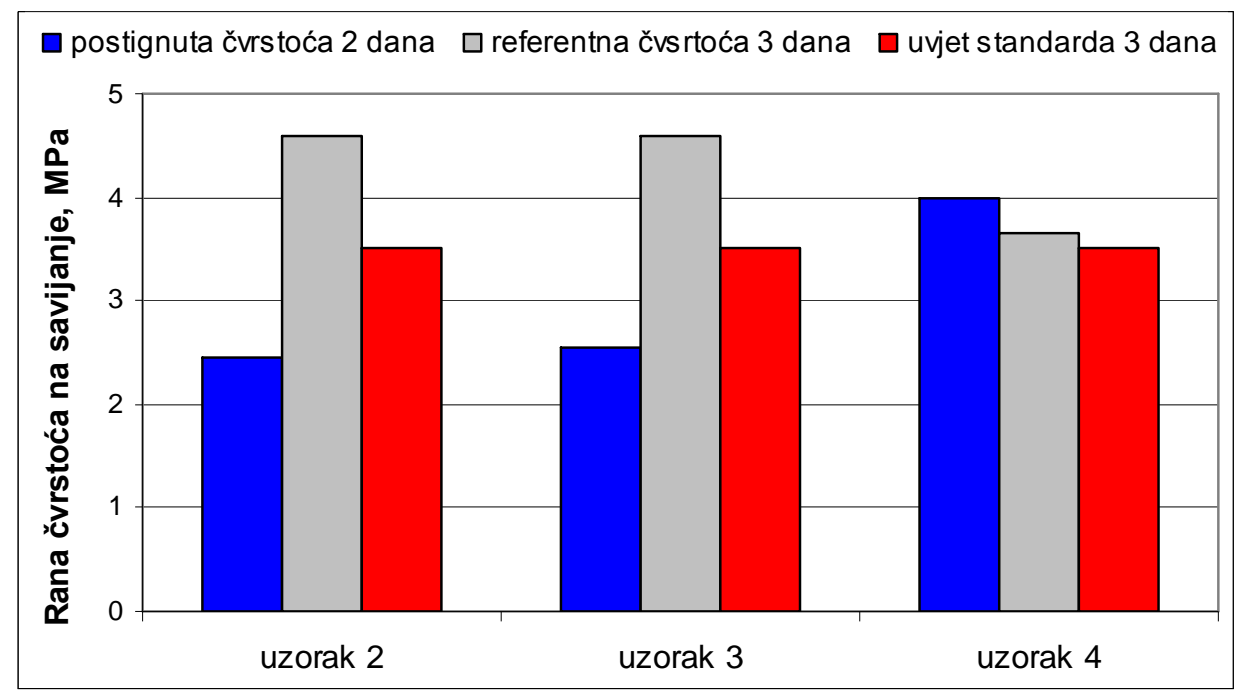

Slika 6 - Čvrstoća na savijanje nakon 2 dana 
Vrijednosti rane čvrstoće na pritisak su slične, slika 7 . Uzorak 4 je postigao traženu vrijednost definiranu standardom, dok za uzorke 2 i 3 ne možemo biti sigurni. normom

Uzorak 5 s 2,62 MPa ima samo 11\% postignute vrijednosti uzorka 6, a nije ni dosegao vrijednost propisanu

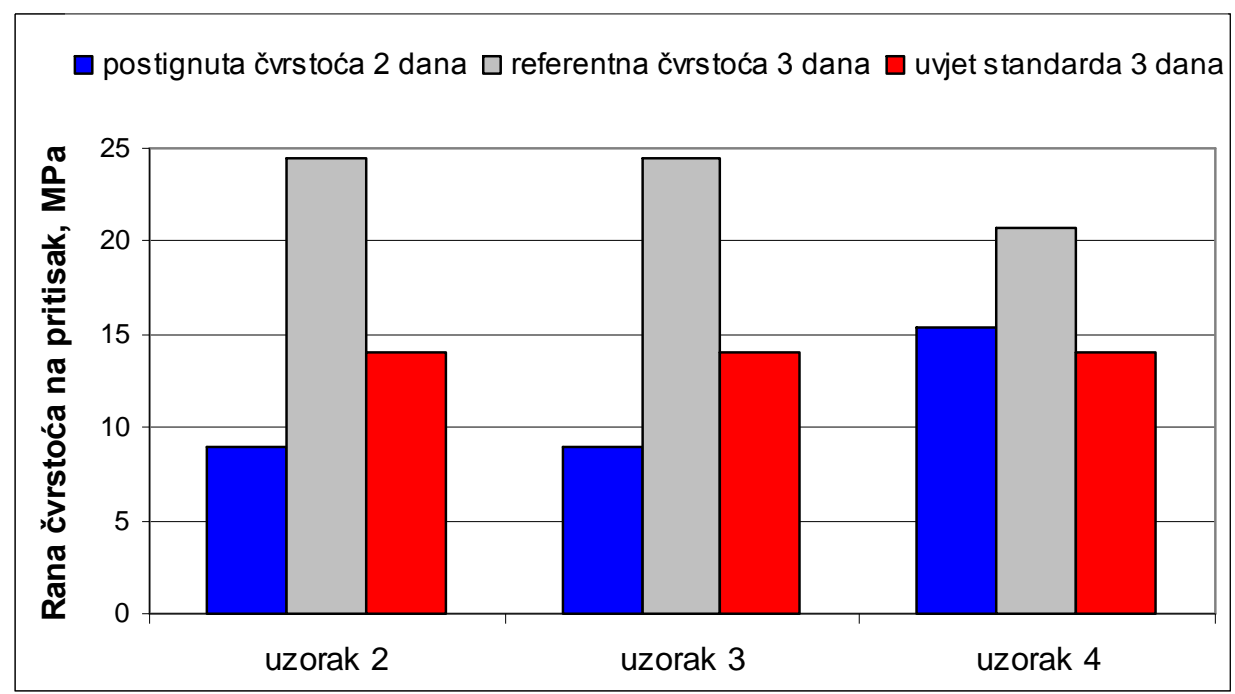

Slika 7 - Čvrstoća na pritisak nakon 2 dana

Čvrstoća na savijanje i pritisak, nakon 28 dana. Srednje vrijednosti rezultata ispitivanja čvrstoće na savijanje i pritisak nakon 28 dana prikazani su na slikama 8 i 9 . U tablici 9 dane su minimalne i maksimalne vrijednosti iz vremena proizvodnje cementa (iz tablice 2) i dobivene ovim ispitivanjem. Prema tablici 9 , razlika između minimalne i maksimalne vrijednosti „starih“ rezultata je puno veća u odnosu na razliku sadašnjih vrijednosti, što se može objasniti činjenicom da su stari rezultati dobiveni kontinuiranom kontrolom proizvodnje cementa kroz nekoliko godina, dok su sadašnji rezultati - rezultati nekoliko uzoraka. Razlike između starih i novih rezultata su veće kod čvrstoća na pritisak i kreću se u rasponu od 5.65 (minimalne vrijednosti - uzorak 2) do 22,59 MPa (maksimalne vrijednosti - uzorak 1).

Tablica 9 - Minimalne i maksimalne vrijednosti čvrstoće na savijanje i pritisak, iz godine proizvodnje cementa i danas

\begin{tabular}{|l|c|c|c|c|c|}
\hline \multirow{2}{*}{ Uzorak } & \multirow{2}{*}{ Vrijeme ispitivanja } & \multicolumn{2}{|c|}{ savijanje } & \multicolumn{2}{|c|}{ pritisak } \\
\cline { 2 - 5 } & & $X_{\min }$ & $X_{\max }$ & $X_{\min }$ & $X_{\max }$ \\
\hline \multirow{2}{*}{ Uzorak 1 } & 1980. & 6,40 & 7,47 & 38,91 & 44,04 \\
\cline { 2 - 6 } & 2012. & 5,24 & 5,78 & 20,59 & 21,45 \\
\hline \multirow{2}{*}{ Uzorak 2 } & 1983. & 7,07 & 8,24 & 42,86 & 50,00 \\
\cline { 2 - 6 } & 2012. & 7,52 & 7,98 & 37,21 & 38,86 \\
\hline \multirow{2}{*}{ Uzorak 3 } & 1983. & 7,07 & 8,24 & 42,86 & 50,00 \\
\hline \multirow{2}{*}{ Uzorak 4 } & 2012. & 7,52 & 8,05 & 36,63 & 38,32 \\
\cline { 2 - 6 } & 1983. & 6,66 & 7,83 & 43,03 & 49,91 \\
\cline { 2 - 6 } & 2012. & 7,09 & 7,56 & 36,36 & 38,31 \\
\hline
\end{tabular}

Prema slici 8, srednja vrijednost 28-dnevne čvrstoće na savijanje uzorka 1 zadovoljava uvjet standarda, ali ne dostiže srednju referentnu vrijednost. Uzorci 2, 3 i 4 su postigli veće vrijednosti od uvjeta standarda i srednje referentne vrijednosti, odnosno približili su se maksimalnoj vrijednosti iz tablice 9. Uzorci 5 i 6 imaju približne srednje vrijednosti od 8.21 i $8.48 \mathrm{MPa}$. 


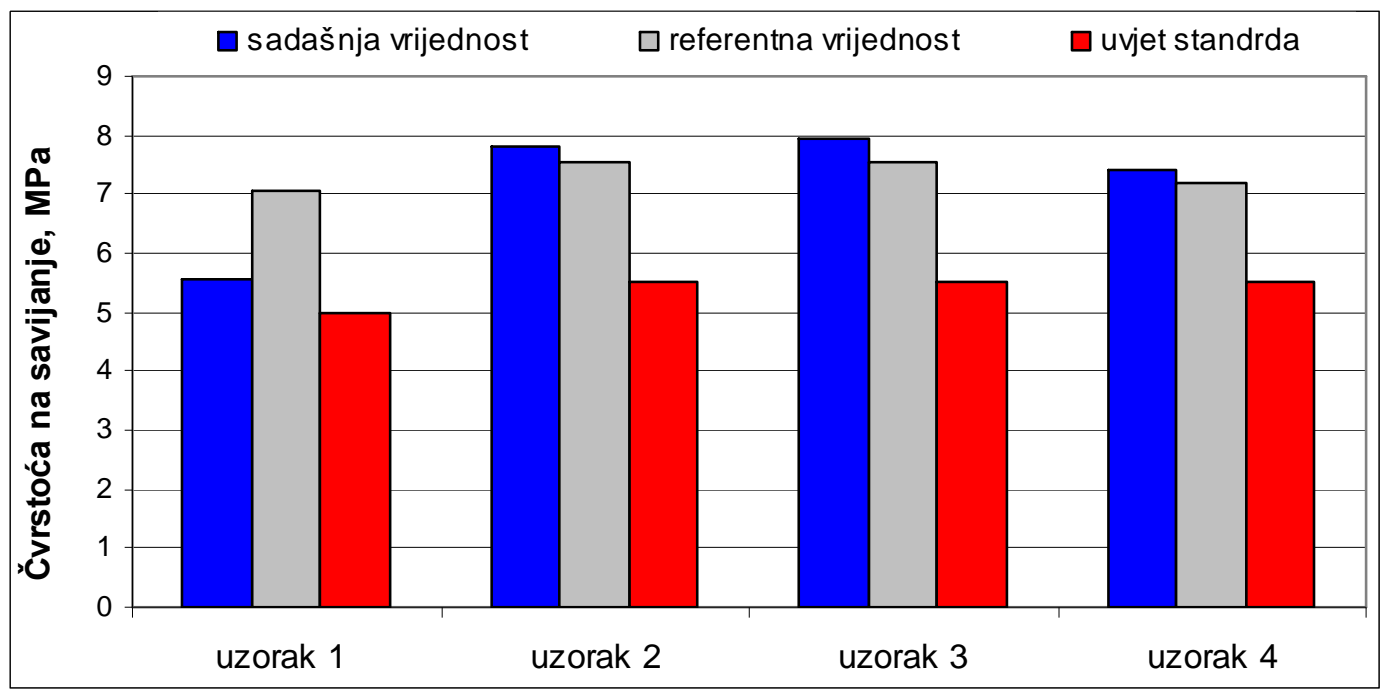

Slika 8 - Čvrstoća na savijanje kod starosti od 28 dana

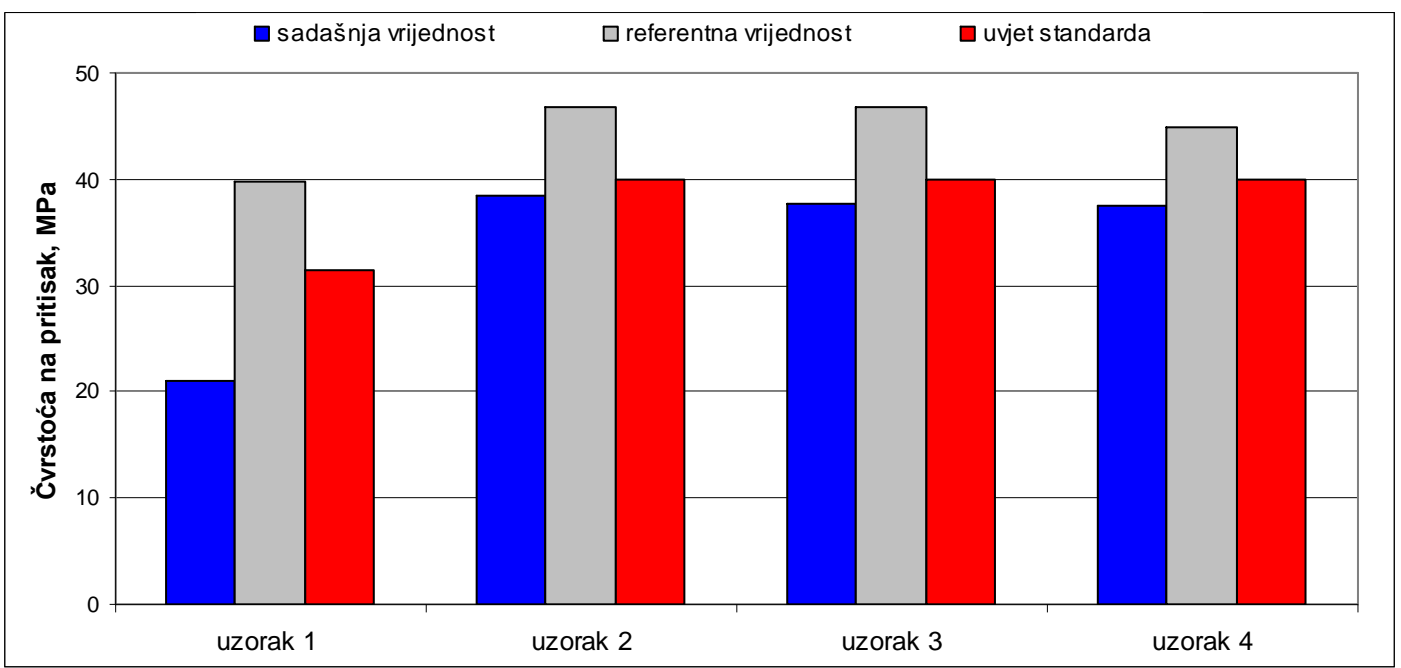

\section{Slika 9 - Čvrstoća na pritisak nakon 28 dana}

Čvrstoća na pritisak uzorka 1 pokazuje najlošiji rezultat, uzorak nije zadovoljio ni uvjet standarda, te je postigao samo $54 \%$ minimalne referentne vrijednosti. S obzirom da je sačuvana količina cementa uzorka 1 bila manja nego za uzorke 2, 3 i 4, vjerojatno se uzorak 1 u međuvremenu otvarao i koristio, te je tako došao u kontakt s vlagom iz zraka. Na to ukazuje i količina grudica na situ $1 \mathrm{~mm}$, čija je količina ista kao i kod loše uskladištenog cementa - uzorak 5 (tablica 6). Čak je i ambalaža u kojoj je čuvan cement uzorka 1 bila drugačija nego kod uzoraka 2, 3 i 4, što ukazuje na naknadnu manipulaciju cementom.

lako uzorci 2, 3 i 4 ne zadovoljavaju uvjet standarda, ostvarenim rezultatima približili su se minimalnim vrijednostima na preko $86 \%$. U usporedbi s podatcima iz literature [5], tj. s petogodišnjim cementom čuvanim u laboratoriju, slika 2, dobivene vrijednosti mogu se smatrati odličnim rezultatima. Uzorak 5, s postignutom vrijednosti od 38,19 MPa, ne dostiže zahtjev norme (42,5 MPa). Smanjenje čvrstoće od $25 \%$ u odnosu na uzorak 6 u skladu je s podatcima iz literature [2]. Uzorak 6 zadovoljava zahtjeve norme te ima najveće postignute čvrstoće od minimalnih 48,6 do maksimalnih 51,35 MPa. 


\section{Zaključak}

Činjenica da je sposobnost vezanja i čvrstoća cementa, kao i proizvoda u kojima je cement osnovni vezivni materijal, ovisna o kemijskoj reakciji cementa s vodom, upućuje nas na brigu o skladištenju i načinu čuvanja cementa sve do momenta uporabe. Kako bi se u najvećoj mjeri sačuvala sva njegova svojstva prilikom čuvanja do momenta uporabe, nužno je osigurati zaštitu od vode i vlage iz zraka.

Dosadašnja ispitivanja pokazala su kako propisno petogodišnje skladištenje ne uzrokuje pogoršanje svojstava cementa, pri čemu pod propisno smatramo da cement nema kontakta sa zrakom, odnosno vlagom iz zraka.

Rezultati ovog ispitivanja na uzorcima cementa starim 30 godina, uspoređeni s rezultatima izvješća tvornica i ovlaštene institucije, ukazuju da dugotrajno skladištenje, čak i u laboratorijskim uvjetima, utječe na kvalitetu cementa, ali su ispitni rezultati ostali u okviru standarda. Očekivano, najstariji uzorak, uskladišten preko 32 godine, pokazao je najlošije rezultate jer je došao u kontakt s vlagom iz zraka, dok su ostali 30-godišnji uzorci ostvarili čak od $80,5 \%$ do $83,3 \%$ vrijednosti tadašnje tlačne čvrstoće. lako ne postoje istraživanja na cementima ovolike starosti, dobiveni rezultati su višestruko bolji u odnosu na podatke iz literature za cemente puno manje starosti [5]. To je pokazatelj da se kod nas proizvodi kvalitetan cement koji dugo zadržava svoja svojstva, iako je deklarirani rok trajanja cementa u neotvorenoj ambalaži između 6 do 12 mjeseci. Noviji cement, namjerno loše uskladišten, postigao je rezultate u okviru dosadašnjih istraživanja.

\section{Literatura}

[1] Krstulović, P.: Svojstva i tehnologija betona, Građevinski fakultet Sveučilišta u Splitu i Institut građevinarstva Hrvatske, Split, 2000.

[2] www.indiacements.co.in

[3] Popović K., Rosković R., Bjegović D.: Proizvodnja cementa i održivi razvoj, Građevinar 55 (2003) 4, 201 206.

[4] Građevinski priručnik, Tehničar1, Građevinska knjiga, Beograd 1954.

[5] Abrams D.A.: Effect of storage of cement, Structural Materials Research Laboratory, Lewis Institute, Chicago, 1924.

[6] McCoy W.J., Helms S.B.: Effect of Storage on Air-Entraining Cements, American Society for Testing Materials, Philadelphia, 1958.

[7] Gonnerman H.F; Timms A.G: A Study of Storage of Portland Cemnet in Report of Director of Research for 1928, Port. Cem. Assnt. Pp. $75-102$

[8] Statistička obrada rezultata ispitivanja cementa iz 1983. godine IGH - PC Split

[9] Novaković L.: Definicija svojstava svježeg mikrobetona Bingham-ovim reološkim modelom, diplomski rad, Građevinski fakultet Split, Split, 1983.

[10] Bezmalinović - Tomac R.: Prostorni model i fizikalne karakteristike uzorka svježeg betona, diplomski rad, Građevinski fakultet Split, Split, 1983.

[11] http://www.cemex.hr/ic/pdf/Tehnicka uputa CEM IIBMSLL425N SvKajo.pdf

[12] Jugoslavensko savjetovanje o primjeni novog pravilnika za beton i armirani beton, Knjiga 2, Dubrovnik 26.29.04.1988.

[13] Furundžić B.: Osnovi tehnologije betona, Građevinska knjiga, Beograd, 1978.

[14] Radić, J. i suradnici: Betonske konstrukcije - priručnik, Hrvatska sveučilišna naklada, Građevinski fakultet Sveučilišta u Zagrebu i Andris, Zagreb, 2006. 